\title{
LITERATURE REVIEW: PEMBERIAN AROMATERAPI ESSENTIAL OIL LAVENDER TERHADAP EMESIS GRAVIDARUM PADA KEHAMILAN TRIMESTER PERTAMA
}

\author{
Ani Retni ${ }^{1 *}$, Fitriya Handayani ${ }^{2}$, Indah Sri Wahyuni Mohamad ${ }^{1}$ \\ 1, Program Studi Ilmu Keperawatan Universitas Muhammadiyah Gorontalo \\ 2, Program Studi S1 Keperawatan Universitas Borneo Tarakan \\ *Email: aniretni@umgo.ac.id
}

\begin{abstract}
Abstrak
Emesis gravidarum adalah ketidaknyamanan umum yang dialami oleh 50\% wanita hamil umumnya terjadi pada trimester pertama. Salah satu penatalaksanaan untuk mengurangi terapi non-farmakologis adalah pemberian aromaterapi lavender. Peneliti bertujuan untuk mengetahui pengaruh pemberian essential oil lavender terhadap emesis gravidarum pada kehamilan trimester pertama. Penelitian ini menggunakan desain studi kepustakaan atau Literature Review. Penelitian ini dilakukan pada bulan Agustus-September 2020 dengan menggunakan 324 artikel yang selanjutnya diseleksi sesuai kriteria inklusi dan eksklusi sehingga menjadi 6 artikel. Pengumpulan data menggunakan metode dokumentasi dengan cara mencari dan menggali data dari literatur. Analisa data secara kualitatif dengan metode berpikir deduktif normatif. Hasil penelitian ini menunjukkan adanya Pengaruh Pemberian Essential Oil Lavender Terhadap Emesis Gravidarum Pada Kehamilan Trimester Pertama. Pengaruh tersebut adalah pengaruh yang positif, dimana pada saat ibu hamil mengalami gejala dari emesis gravidarum yaitu mual-muntah, kemudian mengaplikasikan essential oil lavender sebagai aromaterapi, maka ibu hamil akan merasakan perbedaan antara sebelum dan sesudah pemberian essential oil lavender. Hal ini dikarenakan aroma yang berasal dari essential oil lavender, bekerja melalui sistem limbik dan pusat emosi otak sehingga pemberian essential oil lavender ini direkomendasikan bagi ibu hamil yang mengalami emesis gravidarum.
\end{abstract}

Kata kunci: Essential oil, lavender, Emesis Gravidarum, Ibu Hamil.

\begin{abstract}
Literature Review: Giving Lavender Essential Oil Aromatherapy Against Emesis Gravidarum in First Trimester Pregnancy. Gravidarum Emesis is a common discomfort experienced by 50\% of pregnant women generally occurring in the first trimester. One treatment to reduce non-pharmacological therapy is giving lavender aromatherapy. The researcher aims to determine the influence of giving lavender essential oil on gravidarum emesis in the first trimester of pregnancy. The design of the research was a library research or literature review. This research was conducted in August-September 2020 using 324 articles which were then selected according to inclusion and exclusion criteria so that they became 6 articles. Collecting data was a documentation method by searching and extracting literature data. Qualitative data analysis used normative deductive thinking methods. The results indicated there is the influence of Lavender Essential Oil on Gravidarum Emesis in first Trimester Pregnancy. This effect is a positive effect, when pregnant women experience symptoms of emesis gravidarum such as nausea and vomiting, then applying lavender essential oil as aromatherapy, pregnant women will feel the difference between before and after giving lavender essential oil. This is because the aroma that comes from lavender essential oil works through the limbic system and the emotional center of the brain so that giving lavender essential oil is recommended for pregnant women who experience emesis gravidarum.
\end{abstract}

Keywords: Essential oil, Lavender, Emesis Gravidarum, The Pregnant Women 


\section{Pendahuluan}

Kehamilan merupakan suatu peristiwa yang terjadi pada seorang wanita, dimulai dari konsepsi (Fertilisasi) sampai kelahiran bayi. Setiap ibu hamil pada trimester pertama, mengalami gejala mual-muntah atau disebut dengan emesis gravidarum. Hingga saat ini, masih belum dapat diketahui dengan pasti mengenai alasan terjadinya kasus emesis gravidarum. Akan tetapi, hal ini dapat berhubungan langsung dengan sistem endokrin yang mengalami perubahan, yang terjadi selama proses kehamilan. Terutama, disebabkan oleh tingginya fluktuasi kadar HCG (Human Chorionic Gonadotropin).

Menurut Panca (2015) aromaterapi adalah pengobatan dengan menggunakan kekuatan dari tumbuhan. Aromaterapi menggunakan minyak esensial, yang mengandung zat untuk digunakan tumbuhan guna mempertahankan diri terhadap serangan dari luar, misalnya hama atau serangga. Berbagai jenis aromaterapi, dapat dijadikan sebagai pengobatan non farmakologis guna menurunkan intensitas dari emesis gravidarum bagi ibu, salah satunya yakni penggunaan lavender. Essential oil lavender merupakan pengobatan alternatif, dengan bahan dasar sari tumbuhan aromaterapi murni.

\section{Menurut World Health Organization} (WHO, 2019) jumlah kejadian emesis gravidarum mencapai $12,5 \%$, dari seluruh jumlah kehamilan di dunia, dengan angka kejadian yang beragam yaitu mulai dari 0,3\% di Swedia, 0,5\% di Canada, 10,8\% di China, 0,9\% di Norwegia, 2,2\% di Pakistan, dan $1,9 \%$ di Turki.

Menurut Depkes 2019, angka ibu hamil dengan kasus emesis gravidarum di wilayah Indonesia yakni selama tahun 2019, dari 2.203 angka kehamilan ibu, didapati sebanyak 543 ibu hamil yang menderita emesis gravidarum, di periode awal masa kehamilan. Sehingga, dapat dirata-ratakan angka kejadian kasus emesis gravidarum pada tahun 2019 yakni sebanyak 67,9\%. Dimana, 60 hingga 80\% angka kejadian ini terjadi pada ibu dengan primigravida, serta 40 hingga $60 \%$ angka kejadiannya pada ibu hamil dengan multigravida.

Berdasarkan data yang diperoleh dari rekapitulasi laporan ibu hamil di Dinas Kesehatan Provinsi Gorontalo, pada tahun 2019 berjumlah 4012 orang. Sedangkan yang menderita Morning Sickness, di Kabupaten Gorontalo pada ibu hamil Trimester Pertama, tahun 2019 berjumlah 236 penderita. Masalah dengan kasus emesis pada ibu hamil trimester pertama, masih sering terjadi terutama di pagi hari, dan cara penanggulangannya sebagian besar masih menggunakan terapi farmakologis, seperti minum obat muntah, atau didiamkan saja sampai mual muntah berkurang. 
Menurut pendapat Amiliano (2018) bahwa, dampak emesis gravidarum apabila tidak ditangani dengan baik, maka akan menimbulkan gejala mual muntah yang berat (intractable), serta persisten yang terjadi pada awal kehamilan, sehingga mengakibatkan dehidrasi, gangguan elektrolit, atau defisiensi nutrien. Penderita yang mengalami emesis gravidarum, dengan skala muntah mencapai hingga 10 kali selama 24 jam, maka akan berakibat buruk bagi kesehatan ibu hamil. Hal ini, dapat berpengaruh pada aktivitas seharihari ibu.

Pentingnya judul diangkat karena, kekurangan cairan yang disebabkan oleh muntah, dapat menyebabkan dehidrasi sehingga cairan ekstraseluler dan plasma berkurang. Dapat juga menyebabkan Sindroma Mallory Weiss, yakni suatu kondisi dimana

\section{Metode}

Jenis metode penelitian ini, menggunakan metode tinjauan kepustakaan atau literature review. Literature review merupakan suatu bahan yang ditulis, berupa buku dan jurnal yang membahas mengenai topik, yang akan diteliti. Literature review ini, dapat membantu agar melihat ide-ide, kritik, serta pendapat mengenai topik yang akan diteliti tersebut (Semiawan, 2010).

Teknik pengumpulan data, berasal dari hasil-hasil penelitian yang sudah dilakukan, pada lambung serta selaput lendir dari esofagus telah terjadi suatu robekan.

Oleh karena itu, penelitian dengan kasus emesis gravidarum sangat penting, mengingat dampak bagi ibu dan janin sangat beresiko, bahkan bisa terjadi kematian.

Menurut penelitian lain yang dilakukan oleh Rahayu \& Sugita (2018), ada perbedaan yang signifikan antara mean intensitas derajat mual muntah sebelum dan setelah pemberian aromaterapi lavender.

Berdasarkan uraian tersebut, maka dari itu penulis tertarik untuk melakukan literature review terhadap artikel-artikel yang meneliti tentang pengaruh pemberian essential oil lavender terhadap emesis gravidarum pada kehamilan trimester pertama.

dan diterbitkan dalam jurnal online nasional. Saat melakukan penelitian ini, peneliti melakukan pencarian jurnal yang dipublikasikan di internet menggunakan Google Scholar dan Indonesia One Search, dengan kata kunci: aromaterapi lavender + kehamilan dan lavender + ibu hamil. Dengan sasaran pada penelitian ini yaitu ibu hamil trimester pertama dengan Emesis Gravidarum.

Proses pengumpulan data dilakukan melalui penyaringan, berdasarkan kriteria yang ditentukan oleh peneliti dari tiap jurnal yang 
diambil. Cara penulisan yang efektif untuk setting jurnal dengan memasukkan kata kunci sesuai judul penulisan, dan melakukan penelusuran berdasarkan advance search, dengan penambahan notasi AND/ OR atau +, Misalnya, peneliti melakukan pencarian pada mesin pencarian Google Scholar, dengan mengetik kata "Aromaterapi lavender" + "kehamilan", dan melalui Indonesia One Search dengan "lavender" + "ibu hamil”.

\section{Hasil}

Berdasarkan hasil pencarian artikel, didapatkan 324 artikel dan ditetapkan kriteria inklusi dan eksklusi sehingga didapatkan:

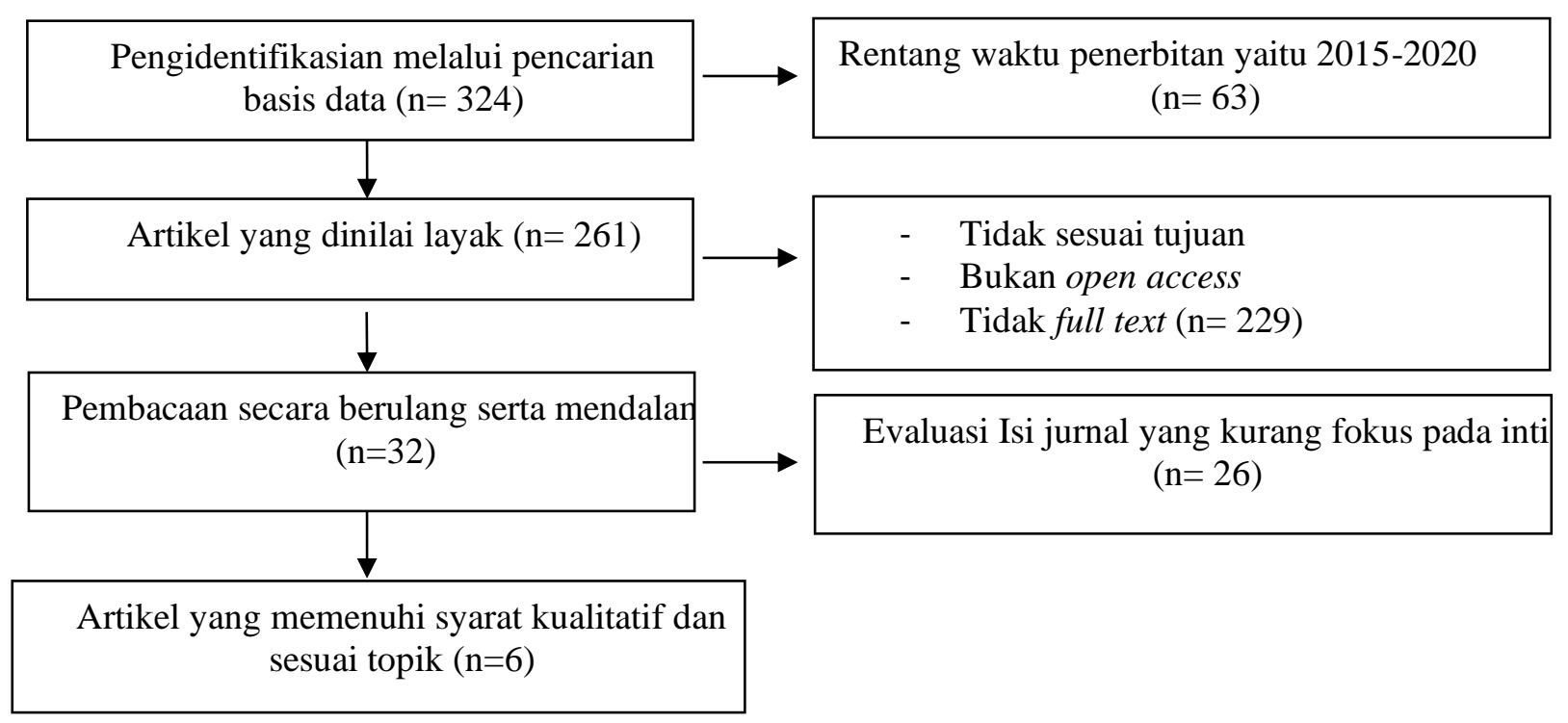

Gambar 1. Alur Penelitian

\section{Pembahasan}

\section{Essential Oil Lavender}

Berdasarkan penelitian yang telah dilakukan oleh Amiliano (2018) dalam melakukan intervensinya pada responden yaitu ibu hamil, peneliti memberikan aromaterapi lavender pada sebuah tissue yang sudah diteteskan dengan aromaterapi lavender sebanyak 2 tetes. Penelitian yang sama dilakukan oleh Panca (2015), dimana intervensi dilakukan selama kurang lebih sekitar 4 hari, yakni ibu hamil diharuskan untuk meneteskan aromaterapi lavender sekitar 2 hingga 3 tetes pada sebuah kapas atau tisu sebanyak 3 kali pernapasan, kemudian diulangi 5 hingga 10 menit kemudian. Penelitian dari Zuraida \& Sari (2017) juga melakukan intervensi yang sama, bahwa aromaterapi lavender diberikan selama kurang lebih 7 hari pada ibu hamil, dengan 
menghirup beberapa tetes aromaterapi pada sebuah tisu.

Teknik intervensi yang berbeda dilakukan pada beberapa penelitian, mengenai pemberian essential oil lavender terhadap emesis gravidarum pada kehamilan trimester pertama. Dimana, berdasarkan penelitianpenelitian tersebut dalam intervensi, menggunakan sebuah wadah elektrik. Pada wadah tersebut, diisi dengan 2 hingga 3 tetes essential oil, kemudian disambungkan ke listrik, agar wadah tersebut dapat bekerja untuk mengubah minyak lavender menjadi uap-uap halus yang dapat dihirup oleh ibu hamil. Uapuap tersebut akan merelaksasikan, serta memberikan efek nyaman dengan waktu penghirupan kurang lebih 24 jam.

Sebagaimana penelitian dari Pratiwi (2018), peneliti menyiapkan satu wadah elektrik yang sudah berisikan air hangat, guna dijadikan sebagai tempat diencerkan minyak lavender. Setelah ibu nyaman, maka wadah yang sebelumnya itu disambungkan ke listrik guna mendapatkan hirupan uap, dari minyak esensial lavender. Wadah elektrik tersebut, dapat digunakan oleh ibu hingga 24 jam agar merasakan manfaatnya. Hal yang sama dilakukan oleh Rossalina (2019), peneliti menggunakan sebuah alat yang bernama diffuser. Dimana, alat tersebut akan mengubah minyak lavender menjadi uap-uap halus. Ibu hamil harus melakukan intervensi ini, selama kurun waktu 3 hari. Kemudian, pada hari ketiga peneliti akan mengambil hasil, dari nilai rata-ratanya. Menurut penelitian Rahayu \& Sugita (2018), peneliti mengharuskan ibu hamil untuk menggunakan aromaterapi lavender, sebanyak kurang lebih 3 kali hingga mencapai hitungan 24 jam.

Lavender merupakan salah satu dari sekian banyak jenis tanaman herbal. Lavender memiliki banyak manfaat, jika dibandingkan dengan tanaman lain. Manfaat yang ada pada lavender, sangat bermanfaat pada ibu hamil dengan gejala mual-muntah. Keunggulan lain dari lavender yakni, kandungannya yang mengandung minyak atsiri atau minyak terbang. Minyak ini sangat menyegarkan, serta dapat memblokir refleks mual-muntah, yang biasanya dialami oleh ibu hamil, pada kehamilan trimester pertama (Pratiwi, 2018)

Lavender mampu melancarkan peredaran darah, serta syaraf-syaraf juga mampu bekerja dengan baik. Kemudian, ketegangan yang dialami akan mengalami penurunan, kepala pun bisa menjadi segar, bahkan keluhan mual-muntah juga dapat diminimalisir dengan baik. Essential oil lavender bisa dijadikan, sebagai suatu stimulus aromatik yang kuat. Hal ini, mampu mengontrol angka pada skala kejadian mualmuntah, dengan cara gerakan peristaltik usus 
yang mengalami suatu peningkatan yang cukup signifikan. (Amiliano, 2018)

Berdasarkan dari suatu teori yang telah dipublikasi oleh jurnal obstetri dan Ginekologi, yakni essential oil lavender yang dijadikan suatu aromaterapi mampu menolong ibu hamil guna menurunkan intensitas derajat mualmuntah yang tengah dialami. Hal ini karena manfaat yang terkandung didalamnya tidak memiliki efek yang dapat membahayakan ibu maupun janin yang dikandungnya. Essential oil lavender dipercaya mampu membantu mengatasi keluhan ibu hamil terhadap kasus emesis gravidarumnya serta dapat mengatasi untuk penurunan intensitas mual-muntah bagi ibu dengan multigravida (Panca, 2015).

Aromaterapi yang sering digunakan yaitu lavender. Aromaterapi ini mempunyai keharuman yang begitu kuat, selain itu juga sangat menyegarkan. Essential oil lavender yakni suatu teknik penyembuhan terbaik, guna mengatasi berbagai masalah pencernaan. Tidak hanya itu, khasiat dari essential oil lavender juga mampu mengobati gangguan pada sistem pencernaan, sembelit, diare, perut yang mengalami sulit buang gas, sangat ampuh meredakan sakit kepala, migrain, serta pingsan. Essential oil lavender telah dikenal lama mampu memberikan efek antispasmodik, juga karminatif, kedua efek ini dikhususkan bekerja pada otot halus, di saluran gastrointestinal serta pada seluruh bagian empedu (Zuraida \& Sari, 2018).

Komponen utama dari suatu tanaman lavender ada beberapa, yakni 1,8-cineole $B$ ocimene, linalool, linalyl acetat, terpinen-4ol, serta kamper. Salah satu komponen dari lavender adalah linalool. Linalool adalah suatu komponen yang mempunyai beberapa efek, yang digunakan sebagai zat sedatif serta penenang. Kandungan-kandungan ini dapat berkhasiat, guna menekan skala mualmuntah yang dialami ibu hamil pada periode awal masa kehamilan. Hal ini, disebabkan oleh kandungan dari senyawa-senyawa tersebut bisa membuat ketenangan, bagi siapapun juga khususnya ibu hamil. (Rossalina, 2019)

Berdasarkan 6 literatur tersebut, maka peneliti dapat berasumsi, bahwa penggunaan essential oil lavender pada ibu hamil dapat dilakukan dengan dua teknik intervensi yakni dengan menggunakan sebuah tisu ataupun kapas kemudian diberikan 2 hingga 3 tetes essential oil lavender, selanjutnya ibu dapat menghirupnya sebanyak 3 kali pernapasan, kemudian diulangi 5 hingga 10 menit berikutnya. Kemudian, teknik lain yang dapat digunakan oleh ibu hamil yakni dengan menggunakan sebuah alat yang bernama diffuser. Dimana diffuser dapat mengubah essential oil lavender menjadi uap-uap halus yang bisa langsung dihirup 
oleh ibu hamil. Ibu hamil dapat menggunakan alat tersebut selama kurang lebih 24 jam, kemudian ibu akan merasakan manfaatnya.

\section{Emesis Gravidarum}

Berdasarkan penelitian dari Rossalina (2019), dengan dilakukannya intervensi pada 15 responden terjadi penurunan intensitas derajat mual-muntah, mulai dari kategori sedang hingga ke kategori ringan. Hasil penelitian yang sama dari Amiliano (2018) menunjukkan setelah pengaplikasian aromaterapi lavender pada ibu hamil, responden ibu hamil berpendapat bahwa saat intervensi dilakukan, mereka merasa jauh lebih nyaman, serta intensitas derajat mual-muntah yang dirasakan ibu hamil sudah berkurang dirasakan, tidak seperti sebelum intervensi dilakukan. Kemudian diperkuat oleh penelitian dari Panca (2015), menurut peneliti setelah diberikannya intervensi aromaterapi lavender, pada responden ibu hamil yang mengalami gejala mual-muntah pada trimester pertama kehamilan, mendapatkan fakta bahwa terjadi penurunan frekuensi mual-muntah ibu hamil, hal ini dikarenakan peneliti melakukan prosedur tindakan dengan menyesuaikan dengan isi dari Standar Operasional Prosedur.

Menurut penelitian dari Zuraida dan Sari (2017) mendapatkan hasil yang sama, dimana mual-muntah ibu hamil, mengalami penurunan setelah diberikannya aromaterapi selama 7 hari. Hal ini juga dipertegas oleh penelitian dari
Pratiwi (2018), ditemukan fakta kelompok eksperimen lebih cepat, memberikan efek bagi ibu hamil jika dibandingkan dengan kelompok kontrol. Hal ini berarti, dengan diberikannya aromaterapi lavender, maka gejala mual-muntah terjadi penurunan, yang signifikan. Dan selanjutnya menurut penelitian Rahayu (2018), dengan teraturnya responden ibu hamil melakukan intervensi maka akan terjadi penurunan intensitas derajat mual-muntah. Hal ini sejalan dengan, pernyataan oleh responden ibu hamil, bahwa perasaan mual yang dialami setelah diberikannya essential oil, berangsur-angsur menurun.

Emesis gravidarum merupakan suatu gejala muntah yang sering terjadi pada awal kehamilan, hingga usia kehamilan kira-kira 20 minggu. Emesis Gravidarum sebenarnya apabila dalam kondisi normal, tidak terlalu berakibat buruk bagi ibu hamil. Akan tetapi, apabila emesis gravidarum tidak ditangani dengan segera, akan mengakibatkan hiperemesis gravidarum. Pada saat itu terjadi, maka tidak menutup kemungkinan ibu akan mengalami gangguan kehamilan. Berdasarkan hasil dari ke 6 literatur yang diperoleh mengenai pemberian essential oil lavender terhadap emesis gravidarum pada kehamilan trimester pertama, maka peneliti dapat berasumsi bahwa intensitas derajat mual-muntah, yang dialami oleh ibu hamil di 
awal masa kehamilan, mengalami penurunan dari skala berat menjadi sedang, kemudian dari sedang menjadi ringan. Dimana, skala mual muntah ibu hamil lebih berkurang setelah diberikannya essential oil lavender, dibandingkan dengan ibu hamil tanpa pemberian essential oil lavender. Penurunan intensitas ini terjadi, apabila ibu hamil teratur mengaplikasikan intervensi, sehingga manfaatnya juga lebih efektif dirasakan ibu hamil.

\section{Pengaruh Pemberian Essential Oil}

\section{Lavender terhadap emesis gravidarum}

Berdasarkan hasil penelitian dari Pratiwi (2018), nilai rata-rata dari mual-muntah sebelum dilakukannya intervensi, sebesar 8.5. Sementara itu, setelah dilakukannya intervensi pada kelompok eksperimen terjadi penurunan menjadi sebesar 1,4 pada hari kedua. Dari hasil tersebut tampak bahwa terjadi penurunan setiap harinya pada kelompok eksperimen. Dari hasil Uji T- Test didapatkan nilai $\mathrm{p}=0,000$ dimana nilai $\mathrm{p}<\alpha(0,05)$ yang berarti pemberian aroma terapi lavender dapat menurunkan mual muntah pada ibu hamil dengan emesis gravidarum. Hasil penelitian dari Amiliano (2018), sebelum dilakukannya intervensi terhadap kelompok eksperimen didapatkan nilai mean 13,18 dengan SD 1,59 sedangkan setelah diberikan intervensi maka didapatkan nilai mean 7,65 dengan SD 1,07. Setelah dilakukan analisis data diperoleh $p$ value $0,000 \quad(\alpha<0,05)$ sehingga disimpulkan adanya penurunan yang signifikan terhadap intensitas mual muntah pada ibu hamil. Sedangkan pada kelompok kontrol, didapatkan nilap $p$ value $0,691>\alpha$ $(0,05)$ yang berarti tidak ada perbedaan antara intensitas mual muntah ibu hamil sebelum dan sesudah dikarenakan pada kelompok ini tidak diberikan aromaterapi lavender. Hal yang sama dilakukan oleh Panca (2015), sebelum dilakukan intervensi didapatkan hasil dengan nilai rata-rata frekuensi mual muntah ibu hamil yaitu sebesar 11,08 dan setelah diberikan intervensi didapatkan penurunan menjadi 8,33 . Dari hasil ini dapat disimpulkan terdapat perbedaan signifikan dari nilai ratarata sebelum dan sesudah pemberian intervensi. Dari hasil analisis data didapatkan $p$ value 0,000 yang artinya $<\alpha$ $(0,05)$ yang berarti bahwa terdapat pengaruh pemberian aromaterapi lavender terhadap penurunan mual muntah pada ibu hamil. Berdasarkan penelitian dari Zuraida (2018), dari sebelum dilakukannya intervensi yakni sebesar 11,42 kemudian sesudah dilakukannya intervensi menurun menjadi sebesar 8,14. Telah terjadi perbedaan dengan rata-rata intensitas derajat mual muntah responden ibu hamil antara sebelum dan setelah pemberian aromaterapi lavender yakni sebesar 3,28 dengan nilai $\mathrm{p}=0,001<$ $\alpha(0,05)$. 
Menurut penelitian Rahayu (2018), peneliti melakukan uji statistik dengan menggunakan uji wilcoxon sehingga memperoleh nilai $\mathrm{p}$ value $(0,000)<\alpha(0,05)$ yang berarti terdapat perbedaan yang signifikan antara intensitas derajat mual muntah sebelum dan sesudah pemberian pemberian aromaterapi lavender pada ibu hamil. Dari penelitian ini juga didapatkan hasil bahwa aromaterapi lavender lebih efektif terhadap mual muntah ibu hamil yaitu 8,50 dibandingkan dengan aromaterapi jahe yaitu sebesar 6,50. Hasil yang sama juga didapatkan dari penelitian Rossalina (2019) yang menggunakan uji statistik T paired menunjukkan hasil analisis dari kelompok eksperimen dan kelompok kontrol pada ibu hamil trimester pertama. Pada kelompok eksperimen (Pemberian aromaterapi lavender) didapatkan $p$ value $0,001<\alpha(0,05)$ sedangkan pada kelompok kontrol (pemberian konseling pengurangan mual muntah) didapatkan nilai $p$ value $0,205>\alpha(0,05)$ sehingga dapat disimpulkan terdapat perbedaan yang bermakna pada kedua kelompok tersebut.

Berdasarkan hasil analisis bivariat dari ke 6 literatur mengenai pemberian essential oil lavender terhadap emesis gravidarum pada kehamilan trimester pertama, maka peneliti dapat berasumsi bahwa, pada saat dilakukannya intervensi dengan pemberian essential oil pada ibu hamil, terjadi pengaruh yang signifikan terhadap intensitas derajat mual muntah ibu.
Hal ini disebabkan karena, hasil yang didapatkan dari kelompok ibu dengan penggunaan essential oil lavender skala mual-muntahnya terjadi penurunan, dibandingkan dengan kelompok ibu tanpa penggunaan essential oil lavender.

Berdasarkan hasil dari literature review, maka peneliti berpendapat bahwa langkah awal guna meminimalisir angka kejadian emesis gravidarum pada kehamilan trimester pertama, bisa melalui terapi non farmakologi, yakni dengan pemberian essential oil lavender. Disamping efeknya tidak menimbulkan bahaya bagi ibu dan janin, lavender juga mudah didapatkan dengan harga yang relatif terjangkau.

Peneliti juga berpandangan bahwa, pemberian essential oil lavender terhadap emesis gravidarum pada kehamilan trimester pertama sangat baik untuk dijadikan intervensi guna menurunkan intensitas derajat mual-muntah yang sering dialami oleh ibu, pada awal masa kehamilan. Saat menjalani proses kehamilan, ibu disarankan untuk mengkonsumsi obat-obatan yang relatif ringan, oleh sebab itu terapi non farmakologi seperti essential oil lavender yang dijadikan sebagai aromaterapi ini, merupakan salah satu pilihan yang terbaik bagi ibu. Apabila, kasus emesis gravidarum tidak ditangani dengan segera, maka akan berakibat buruk bagi kesehatan ibu, yang 
bisa berdampak pada tumbuh kembang janin. Hal ini terjadi karena, asupan nutrisi ibu yang tidak terpenuhi, disebabkan oleh mual muntah yang dialami.

\section{Kesimpulan}

Studi literatur pada 6 literatur penelitian yang relevan mengenai pengaruh pemberian essential oil lavender terhadap emesis gravidarum pada kehamilan trimester pertama, didapatkan adanya pengaruh antara pemberian essential oil lavender terhadap emesis gravidarum pada kehamilan trimester pertama. Berdasarkan hasil dari penelitian-penelitian tersebut, peneliti dapat berkesimpulan bahwa pengaruh tersebut adalah pengaruh yang positif, dimana pada saat ibu hamil mengalami gejala dari emesis gravidarum yaitu mualmuntah, kemudian mengaplikasikan essential oil lavender sebagai aromaterapi, maka ibu hamil akan merasakan perbedaan antara sebelum dan sesudah pemberian essential oil lavender. Hal ini dikarenakan aroma yang berasal dari essential oil lavender, bekerja melalui sistem limbik dan pusat emosi otak. Pada saat minyak dihirup, molekul yang mudah menguap dari minyak, dibawa oleh udara ke hidung, sehingga silia-silia yang lembut muncul dari sel-sel reseptor. Aroma yang dihirup melalui proses pernafasan ini, kemudian merangsang kinerja otak. Hal ini, juga dipengaruhi oleh dalamnya pernafasan, sehingga mengakibatkan penurunan mual.

\section{Referensi}

Amiliano, S. (2018). Pengaruh Pemberian Aromaterapi Lavender (lavandula angustifolia) terhadap Penurunan Mual dan Muntah Ibu Hamil Trimester

I di Puskesmas Dangung-Dangung Kabupaten Lima Puluh Kota. JOM FKp, 7 No. 1, 7-13.

Conny R, Semiawan. (2010) Metode Penelitian Kualitatif: Jenis, Karakteristik dan Keunggulannya. Jakarta: Gramedia Widiasarana

Depkes R.I. (2019) Hubungan antara Status Gravida dan Usia Ibu dengan Kejadian Emesis Gravidarum. ISSN Cetak 2303-1433 ISSN Online: 2579-7301.

Dinkes. (2019). Profil Kesehatan Provinsi Gorontalo Tahun 2019. Gorontalo: Dinas Kesehatan Provinsi Gorontalo

Panca, R. P. (2015). Pengaruh Pemberian Aromaterapi Lavender Terhadap Penurunan Mual Dan Muntah Pasien Emesis Gravidarum Di Rsup Dr. M. Djamil Padang 2015. Jurnal Keperawatan Unand, 12(1), 41-46.

Pratiwi, R., Misrawati, \& Zulfitri, R. (2018). Efektifitas Pemberian Aromaterapi Lavender dalam Menurunkan Rasa Mual dan Muntah pada Pasien 
Hiperemesis Gravidarum. Jurnal Ners Indonesia, 2(1), 60-69.

Rahayu, R., \& Sugita, S. (2018). Efektivitas Pemberian Aromaterapi Lavender Dan Jahe Terhadap Penurunan Frekuensi Mual Muntah Pada Ibu Hamil Trimester I Di BPM Trucuk Klaten. Jurnal Kebidanan Dan Kesehatan Tradisional, $3(1)$, 19-26. https://doi.org/10.37341/jkkt.v3i1.62 Rosalinna. (2019). Aromaterapi Lavender Terhadap Pengurangan Mual Muntah Pada Ibu Hamil. Jambura Health and Sport Journal, 1(2), 48-55. Retrieved from http://garuda.ristekbrin.go.id/documents/ detail/1641431

Zuraida, \& Sari, E. D. (2018). Perbedaan Efektivitas Pemberian Essential Oil Peppermint dan Aroma Terapi Lavender terhadap Intensitas Mual dan Muntah pada Ibu Hamil Trimester I di Puskesmas Baso Kabupaten Agam Tahun 2017. Menara Ilmu LPPM UMSB, 12(4), 142151. 